\title{
Ciclos econômicos e periodização da rede urbana no Amazonas-Brasil as cidades Parintins e Itacoatiara de 1655 a 2010
}

Tatiana Schor ${ }^{1} \mathrm{e}$

Thiago Pimentel Marinho²

\section{Resumo}

Ao se analisar a periodização da rede urbana na Amazônia que ora evidencia crescimento, expansão, ora evidencia estagnação econômica na região, é possível perceber o fortalecimento e a representatividade de determinados núcleos urbanos que por fatores histórico-geográficos se destacam desde a sua fundação como nos de grande expressividade. Assim, este artigo tem como objetivo analisar a espaço-temporalidade das cidades de Parintins e Itacoatiara e seus papéis na rede urbana do estado do Amazonas, Brasil. Este trabalho pretende colaborar com discussões sobre cidades da Amazônia Brasileira, especialmente do Amazonas, visualizando a rede urbana, muito mais complexa do que se vê até o momento, por meio de estudos em escala regional e nacional.

\section{Palavras-chave}

Ciclos econômicos no Amazonas, periodização, rede urbana, cidades médias.

Recebido em 18 de abril de 2013

Aprovado em 12 de junho de 2013

SCHOR, Tatiana; MARINHO, Thiago Pimentel. Ciclos econômicos e periodização da rede urbana no Amazonas - Brasil: as cidades Parintins e Itacoatiara de 1655 a 2010. Revista do Instituto de Estudos Brasileiros, Brasil, n.56,p. 229-258, jun. 2013. D0I: http://dx.doi.org/10.11606/issn.2316-901X.v0i56p229-258

1 Universidade Federal do Amazonas (UFAM, Manaus, AM, Brasil).

2 Universidade Federal do Amazonas (UFAM, Manaus, AM, Brasil). 


\title{
Economic Cycles and Periodization of the Urban Network in Amazonas The Cities of Parintins and Itacoatiara - 1655 to 2010
}

Tatiana Schor and

Thiago Pimentel Marinho

\begin{abstract}
When analyzing the periodization of the urban network in the Amazon different aspects evidence growth and expansion, while others evidence economic stagnation. In any of these cases it is possible to notice the strengthening of certain urban centers, that due to historical-geografical factors, highlight their importance in the urban network of the Amazonas State -Brazil. Aiming to analyse the spatial temporality of the cities of Parintins and Itacoatiara and their role in the urban network along the Amazonas river, this paper presents historical data, results from extensive field work and comprehensive analysis of both cities. This analysis gives new light in the understanding of the urban network in the Brazilian Amazon, considering a different scale to those usually used to understand urbanity in the region.
\end{abstract}

Keywords

Economic cycles in Amazonas, periodization, urban network middle cities. 


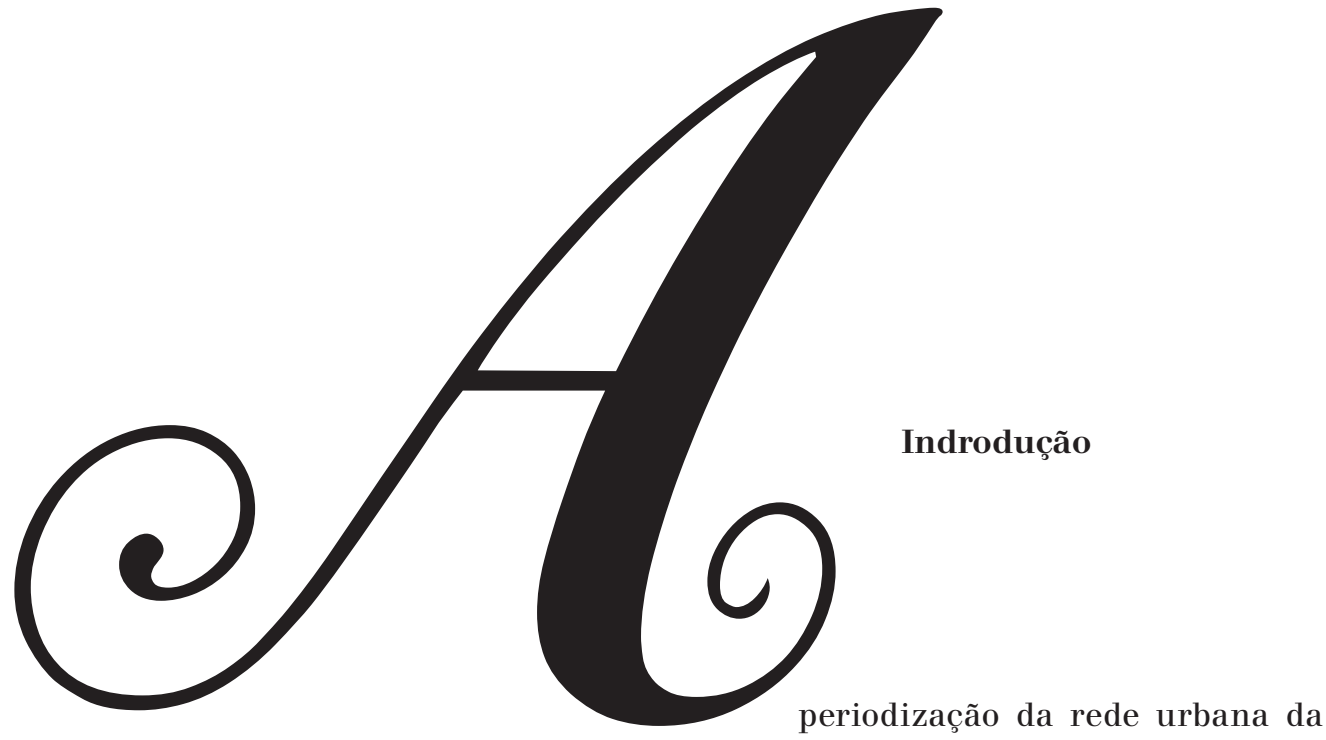

Amazônia ${ }^{3}$ que ora evidencia crescimento, expansão, ora evidencia estagnação econômica na região revela o fortalecimento e a representatividade de determinados núcleos urbanos que não podem ser considerados grandes nem pequenos, mas sim como cidades médias ${ }^{4}$, que por fatores histórico-geográficos, destacam-se na rede urbana regional desde a sua fundação como nos de grande expressividade. Estas cidades exercem principalmente papéis de interligação entre as cidades grandes (as capitais Manaus/AM e Belém/PA) e os aglomerados humanos que se estabeleceram ao longo das calhas dos rios e no interior da floresta. Além do papel de interligar, essas cidades tiveram ciclos econômicos distintos das grandes e pequenas cidades que compõem a rede urbana da Amazônia Brasileira e por isso apresentam características marcantes que mesmo findando os ciclos econômicos perpetuam suas atuações na rede. Atualmente, se destacam também como sedes de consumo de bens e serviços, tornando-se centros importantes de urbanização no coração da floresta.

As cidades de Parintins e Itacoatiara são exemplos desse processo no estado do Amazonas. Localizadas às margens do rio Amazonas, ambas destacam-se como cidades médias com funções diferenciadas e complementares. Desde suas origens, destacam-se na rede urbana do estado, tanto no período de crescimento econômico quanto no de estagnação,

3 CORREAA, R. A periodização da rede urbana na Amazônia. Revista Brasileira de Geografia, Rio de Janeiro: IBGE n. 49, v. 3, p. 39-68, 1987.

4 SCHOR, T.; COSTA, D.; OLIVEIRA, J A. Cidades, rede urbana e desenvolvimento na Amazônia dos Grandes Rios. In: TRINDADE JR., S.; CARVALHO, G.; MOURA, A.; GOMES NETO, J. (Orgs.). Pequenas e médias cidades na Amazônia. Manaus: Fase/ UFPA, 2009, p. 35-58. 
promovendo estratégias de dinamismo por meio de atividades locais que vieram a se desenvolver, como é o caso da juta no período de estagnação econômica, pós-declínio da economia da borracha. Atualmente, aliado com atividades econômicas como o setor agropecuário em Parintins e Terminal Portuário Privativo Misto de Itacoatiara aliam-se atividades culturais-espetaculares como é o caso do Festival Folclórico do Boi-Bumbá em Parintins de âmbito internacional e na escala regional o Festival da Canção de Itacoatiara (Fecani) que dão uma dinâmica diferenciada às duas cidades (Figura 01$)^{5}$.

O entendimento da dinâmica urbana dessas cidades, sua geografia histórica e sua função como cidades médias na rede urbana do Amazonas, em especial do rio Amazonas, é de suma importância para se compreender o complexo processo de urbanização e desenvolvimento que a Amazônia Ocidental apresenta. Neste contexto, este artigo tem o intuito de colaborar com as discussões sobre a urbanização na Amazônia Ocidental e das cidades amazônicas, especialmente as cidades médias, afirmando que se forem considerados critérios locais na análise, além dos gerais, é possível visualizar um mapa da Amazônia com uma rede urbana muito mais complexa do que se vê até o momento, o que proporcionará melhor entendimento sobre a importância das cidades médias, como Parintins e Itacoatiara, na manutenção das cidades de sua rede e quiçá na preservação da sociobiodiversidade da região.

Para alcançar estes objetivos, discutiremos de início, duas interpretações sobre a rede urbana no Amazonas; a primeira, proposta pelo IBGE no seu estudo Regiões de influência das cidades - 2007 e a segunda, elaborada pelo Núcleo de Estudos e Pesquisas das Cidades da Amazônia Brasileira (Nepecab). Em seguida será analisado o impacto da interiorização do ensino superior realizado pelas universidades públicas (Universidade Federal do Amazonas - Ufam e Universidade do Estado do Amazonas - UEA) nas cidades de Parintins e Itacoatiara e como esta variável complexifica o entendimento de rede urbana na região Norte do Brasil. Conclui-se que o ensino superior redefine alguns aspectos da rede urbana, em especial com relação aos processos migratórios na região Norte e consolida o papel de cidades médias tanto em Parintins quanto em Itacoatiara.

5 As figuras, assim como as tabelas e gráficos estão localizados no final do artigo, logo após os créditos dos autores. [N.E.] 


\section{A relevância das cidades médias na manutenção da rede urbana no Amazonas: análise comparativa de duas propostas metodológicas}

O objetivo deste item é estabelecer um paralelo entre duas linhas de pensamento sobre a rede urbana no Amazonas a fim de levantar questionamentos sobre a representatividade das cidades de Parintins e Itacoatiara no Estado. A primeira é o trabalho desenvolvido pelo Instituto Brasileiro de Geografia e Estatística (IBGE) na sua publicação mais recente, Regiões de influência das cidades - 2007. A segunda é o trabalho desenvolvido pelo Núcleo de Estudos e Pesquisas das Cidades da Amazônia Brasileira (Nepecab), vinculado à Universidade Federal do Amazonas (Ufam), a partir do Programa de Estudo e Pesquisa da Rede Urbana da calha do rio Solimões-Amazonas/AM ${ }^{6}$. As cidades que serão analisadas neste item são as localizadas na calha do rio Solimões-Amazonas devido serem estas a se destacar nos dois trabalhos (Figura 02).

O trabalho Regiões de influência das cidades - 2007 é uma reformulação dos primeiros estudos realizados pelo Instituto Brasileiro de Geografia e Estatística (IBGE) que classificavam os centros urbanos e posteriormente delimitavam suas áreas de atuação. Contudo, o atual estudo privilegia a função de Gestão do Território, que de acordo com Roberto Lobato Corrêa é “aquela cidade onde se localizam, de um lado, os diversos órgãos do Estado e, de outro, as sedes de empresas cujas decisões afetam direta ou indiretamente um dado espaço que passa a ficar sobe o controle da cidade através das empresas nela sediadas"7.

O processo de construção da pesquisa do IBGE foi dividido em três etapas. A primeira foi à utilização de dados primários e secundários. Os níveis de Gestão Território foram construídos com base nos registros administrativos de órgãos estatais e empresariais. Para garantir a inclusão de centros especializados não selecionados, pelo primeiro critério e qualificar melhor a centralidade dos núcleos selecionados foram adicionados diferentes equipamentos e serviços na análise: atividades de comércio e serviços, atividade financeira, ensino superior, serviços de saúde, internet, redes de televisão aberta e transporte aéreo.

6 OLIVEIRA, J.; SCHOR, T. Urbanização na Amazônia: o local e o global. In: VAL, A.; SANTOS, G. (Orgs.). Caderno de Debates. Manaus: Grupo de Estudos Estratégicos Amazônicos - INPA, t. III, p. 145-189, 2010; SCHOR, T.; COSTA, D.; OLIVEIRA, J. A. Cidades, rede urbana e desenvolvimento na Amazônia dos Grandes Rios, op. cit.

7 INSTITUTO BRASILEIRO DE GEOGRAFIA E ESTATÍSTICA. Regiões de influência das cidades - 2007. Rio de Janeiro: IBGE, 2008. 
Para esse último foi construído um questionário para a pesquisa preenchido pela Rede de Agências do IBGE que investigou: 1) as principais ligações de transportes regulares, em especial as que conduzem aos centros de gestão e 2) os principais destinos dos moradores pesquisados para obtenção de produtos e serviços (compras em geral, ensino superior, aeroportos, serviços de saúde, fluxos para aquisição de insumos e o destino de produtos agropecuários). As informações do questionário não foram quantificadas e o informante é o próprio agente do IBGE que, "por realizar pesquisas regulares e percorrer o território tem conhecimento de sua área de jurisdição e acesso a fontes locais para confirmar as informações solicitadas"8.

Na etapa seguinte, a partir da análise das ligações entre as cidades tornou-se possível então estabelecer as suas áreas de influência e esclarecer a articulação das redes do país. Segundo o $\mathrm{IBGE}^{9}$ as informações coletadas demonstraram a diferença entre o conjunto de centros urbanos com maior centralidade dos de gestão de território. Há cidades que apesar de não serem classificadas como centro de gestão do território, tiveram suas centralizadas identificadas a partir do efeito de atração que exercem sobre as demais. Enquanto algumas cidades classificadas como centros de gestão territorial mantinham atuação restrita ao próprio município, com funções centrais usufruídas apenas pela população local.

A etapa final, a hierarquização proposta para os centros urbanos brasileiros considerou: a classificação dos centros de gestão do território, a intensidade de relacionamentos ${ }^{10}$ e a dimensão da região de influência de cada centro, assim como as diferenciações regionais. Com esse critério adotado, a análise visa levar em consideração essa especificidade, hierarquizando os centros urbanos a partir de sua importância para o espaço em que está inserido. "Assim, centros localizados em regiões menos densamente ocupadas, em termos demográficos ou econômicos, ainda que apresentem indicativos de centralidades mais fracos do que os de centros localizados em outras regiões, podem assumir o mesmo nível na hierarquia"11.

A hierarquia dos centros urbanos, identificando as áreas de influência dos centros urbanos foram identificadas a partir da intensidade das ligações entre as cidades, tendo por base dados secundários e dados

8 Idem, Ibidem, p. 9 .

9 Idem, Ibidem.

10 O número de relacionamentos foi calculado pelo IBGE pelo número de vezes em que, no questionário da pesquisa, o centro foi mencionado como destino Idem,Ibidem.

Idem, Ibidem, p. 11. 
obtidos pelo questionário específico da pesquisa, e foram classificadas em cinco grandes níveis, por sua vez subdivididos em dois ou três subníveis (Tabela 01).

O fato de o Centro-Sul do Brasil contar com um número maior de metrópoles, capitais regionais e centros sub-regionais em relação às regiões Norte e Nordeste que apresentam distribuição truncada com ausência de níveis hierárquicos faz com que estes se apresentem de forma desigual no território.

No Amazonas, a capital Manaus é classificada como metrópole (c), as cidades de Parintins e Tefé centros sub-regionais (b), Itacoatiara e Tabatinga centros de zona (a), e as demais cidades centros locais. A cidade de Manaus controla a rede urbana do estado e mantêm interação com Boa Vista (RR) caracterizada como capital regional (b).

Apesar do uso de metodologia que valoriza a importância dos centros urbanos no espaço em que estão inseridos, mesmo que estejam localizados "em regiões menos densamente ocupadas, em termos demográficos ou econômicos, [e apresentando] indicativos de centralidades mais fracos do que centros localizados em outras regiões"12, podendo vir a assumir o mesmo nível hierárquico desses, a hierarquia urbana no Amazonas com uma metrópole (c) e apenas dois centros sub-regionais (b), revela o que poderia ser uma rede urbana bastante deficitária e pulverizada, sendo que o estado possui 62 municípios.

Segundo Schor, Costa e Oliveira ${ }^{13}$, as classificações do IBGE para a rede urbana no Amazonas são insuficientes para caracterizar suas cidades, fazem-se necessárias outras definições históricas, econômicas, sociais e funcionais que definam a forma e a função delas. Assim, o programa de pesquisa Rede Urbana na calha do rio Solimões-Amazonas (AM) realizado pelo Nepecab propõe uma tipologia própria para a compreensão da dinâmica espacial das 25 cidades que compõem a calha.

Ainda de acordo com os mesmos autores, uma das maneiras de se entender a dinâmica urbana é via classificação ou tipificação das cidades que pode tomar rumo à construção do "tipo ideal" de Max Weber (Economia e Sociedade) ou pode simplesmente reconhecer padrões de funcionamento e de dinâmica urbana e categorizá-los em tipos. É desta segunda alternativa, a classificação que relaciona semelhanças e diferenças e a tipologia que reconhece padrões, que se estende o estudo da tipologia urbana para as cidades do Amazonas.

12 Idem, Ibidem, p. 10.

13 SCHOR, T.; COSTA, D.; OLIVEIRA,J. A. Cidades, rede urbana e desenvolvimento na Amazônia dos Grandes Rios, op. cit. 
Para se construir a tipologia proposta à rede urbana do estado do Amazonas delimitou-se alguns arranjos institucionais que poderiam, se analisados em conjunto, estabelecer uma hierarquia urbana para essas cidades $^{14}$ (Tabela 02).

Os arranjos institucionais permitiram a construção de uma tipologia própria para a rede urbana analisada a partir da infraestrutura existente, buscando compreender as dinâmicas internas e externas de cada cidade. Com isso foi possível elaborar tipos de cidades que são classificadas pelo seu papel na dinâmica da rede urbana ${ }^{15}$ (Tabela 03).

Nesta pesquisa a cidade de Manaus não foi analisada de forma conjunta com as demais cidades da calha, isso de deve ao fato de ela possuir números superiores a qualquer outra cidade do estado. Um exemplo é a rede bancária, em Manaus no ano de 2007 existiam 77 agências e em Parintins e Itacoatiara, apenas quatro agências cada uma ${ }^{16}$.

Analisando as cidades a partir de dados estatísticos, todas as 24 cidades estariam no mesmo nível na rede urbana, exceto a cidade de Manaus, contudo a exclusão desta revela dinamismo maior entre as cidades da calha, lideradas por Tabatinga, Tefé, Manacapuru, Itacoatiara e Parintins, configurando uma rede urbana e uma classificação de cidades baseadas na importância que cada cidade desempenha na manutenção da rede urbana da qual faz parte. Isso se deve à desmistificação da Amazônia como região carente, em todas as acepções da expressão, utilizando uma metodologia que valoriza também as especificidades locais e não somente a presença e ausência de equipamentos e serviços.

Contudo, as 24 cidades não pertencem a uma única rede urbana, os dados dessa pesquisa realizada pelo Nepecab possibilitaram reflexões preliminares como a diferença na rede urbana das cidades do rio Solimões e as do rio Amazonas (AM) ${ }^{17}$. A rede urbana no rio Solimões possui uma dinâmica local e infraestrutura bastante precária com modesta inserção na dinâmica de desenvolvimento regional e nacional. No rio Amazonas (AM), sua rede é caracterizada por ser mais homogênea no referente

14. OLIVEIRA, J. ; SCHOR, T. Urbanização na Amazônia: o local e o global, op. cit.

15 Idem, Ibidem.

16 ALVES, Juliana Araújo. Tipificação da rede urbana na calha do Solimões: espaço urbano e serviços bancários de Manacapuru e Coari. Relatório de Pesquisa de Iniciação Científica. Programa Institucional de Bolsas de Iniciação Científica/Pibic, Universidade Federal do Amazonas, Manaus, 2007. CORRÊA, R. A periodização da rede urbana na Amazônia. Revista Brasileira de Geografia - , Rio de Janeiro, IBGE n. 49 , v. 3, p. $39^{-68}, 1987$.

17 O rio Solimões recebe este nome quando entra no Brasil em Tabatinga até a cidade de Manaus quando, ao se encontrar com o rio Negro, torna-se rio Amazonas até a sua foz em Belém, capital do estado do Pará. 
à disponibilidade de infraestrutura e de fluxos entre as cidades que a compõem. Isso se deve ao rastro deixado pelos fluxos vindos de Belém e Santarém, no estado do Pará, para Manaus. Além disso, Itacoatiara dispõe de seu terminal portuário recebendo os fluxos vindos de Rondônia e Mato Grosso pela hidrovia do Madeira. Em Parintins, o Festival Folclórico do Boi-Bumbá, o maior do Brasil, dá importância crescente à cidade tornando-se conhecida nacional e intercionalmente ${ }^{18}$.

Mas apesar dos estudos iniciais realizados pelo Nepecab apontarem as cidades de Itacoatiara e Parintins como pertencentes à mesma rede, o aprofundamento e detalhamento da rede urbana ao longo do rio Amazonas no estado do Amazonas mostra outra realidade. A análise dos ciclos econômicos e da dinâmica atual das cidades revela que estas não pertencem à mesma rede urbana. Pelo contrário, estabelecem redes urbanas distintas. As duas cidades, mesmo possuindo uma infraestrutura melhor do que as da calha do rio Solimões e de coincidirem nos ciclos econômicos, as duas cidades possuem dinâmicas distintas, conforme será apresentado ao longo deste artigo.

A classificação realizada pelos estudos do Nepecab, em especial para a cidade de Parintins, a partir de uma análise mais verticalizada, revela-se insuficiente. Considerar Parintins como uma cidade de dinâmica econômica externa é não perceber a importância que esta cidade tem na conformação da rede urbana do rio Amazonas (AM), na fronteira entre os estados do Amazonas e do Pará. A periodização da rede urbana de Parintins revela dinâmicas econômicas que vão além da escala do local, apresentando fortes vínculos com os municípios ao seu redor abrangendo o estado do Pará, como exemplificado pela rede de educação superior. Consideramos Parintins não mais como cidade de dinâmica econômica externa, mas sim como de responsabilidade territorial.

Nesse contexto é importante lançar um novo olhar sobre a periodização da rede urbana, para isso propomos no item a seguir uma periodização da rede urbana tendo como foco as cidades de Itacoatiara e Parintins.

18 SCHOR, T.; COSTA, D.; OLIVEIRA, J. A. Cidades, rede urbana e desenvolvimento na Amazônia dos Grandes Rios, op. cit. ,OLIVEIRA, J. ; SCHOR, T. Urbanização na Amazônia: o local e o global, op. cit. 


\section{Periodizando a rede urbana de Itacoatiara e Parintins}

Segundo Corrêa ${ }^{19}$ a periodização espacial reconstrói o tempo espacial, ou seja, coloca em evidência momentos diferenciados que caracterizam o processo de elaboração da organização espacial. Assim propõe-se analisar a representatividade na rede urbana do estado do Amazonas das cidades de Itacoatiara e Parintins a partir da periodização da rede urbana da Amazônia.

Ao reconstruir a periodização da rede urbana das cidades de Itacoatiara e Parintins evidencia-se que estas surgem como consequência do processo de intensificação da ocupação luso-brasileira na Amazônia a partir do século XVII. Segundo A. Oliveira,- ${ }^{20}$, a ocupação da Amazônia brasileira a partir da chegada dos luso-brasileiros na foz do rio Amazonas, em 1616, foi um fato essencialmente político da coroa portuguesa, apesar das coroas de Portugal e Espanha estarem unidas e sob o comando da segunda nesse período.

A ocupação do vale amazônico pelos luso-brasileiros que se apresentava com a finalidade de expulsar os concorrentes (ingleses e holandeses), na realidade, tinha o desejo de explorar o mercado do açúcar e das “drogas do sertão" 21 que só poderia ser realizado com a ocupação dessa área que se deu por meio de guerras aos invasores e de construção de fortes. Além dos ingleses e holandeses, os índios constituíram-se como "empecilhos" dessa ocupação, daí a necessidade das missões religiosas a fim de fazer descê-los de suas aldeias para as povoações religiosas, servindo de mão de obra ${ }^{22}$.

Como ponto de penetração e conquista do território a cidade de Belém é fundada pelos portugueses vindos de São Luís (Maranhão), desenvolvida a partir da criação do Forte do Presépio em 1616. O Forte tornou-se base para as expedições militares portuguesas que tinham como intenção expulsar ingleses, franceses e holandeses que já mantinham comércio na região. Além disso, a cidade, por sua posição geográfica, tornou-se a porta de entrada e saída da Amazônia o que lhe competirá papel importante na região ${ }^{23}$.

19 CORRÊA, R. A periodização da rede urbana na Amazônia, op. cit.

20 OLIVEIRA, A. Ocupação humana. In: SALATI, E.; SHUBART, H.; JUNK, W.; OLIVEIRA, A. (Orgs.). Amazônia: desenvolvimento, integração, ecologia. São Paulo/ Brasília: Brasiliense/Conselho de Desenvolvimento Científico e Tecnológico/ CNPq, 1983, p. 144-327.

21 Nome dado às especiarias como cacau, salsaparrilha, urucu, cravo, canela, anil, sementes oleaginosas, raízes aromáticas, puxiri, baunilha e madeira encontradas na floresta Amazônica (Idem, Ibidem).

22 Idem, Ibidem.

23 CORRÊA, R. A periodização da rede urbana na Amazônia, op. cit. 
As “drogas do sertão" tornaram-se, com a perda dos mercados produtores de especiarias na Ásia, o principal comércio mantido por Portugal na Amazônia a partir de 1655, devido ao seu alto valor na Europa. Os fortins e aldeias missionárias com a utilização de mão de obra indígena eram a base desse comércio no período que se estende da metade do século XVII ao final da primeira metade do século XVIII.

A fim de adquirir posição vantajosa, controlando a circulação de um vale, as aldeias e fortins localizavam-se, principalmente, às margens do rio Solimões-Amazonas e, em muitos casos na confluência de um afluente. Como exemplos têm-se a Aldeia dos Tapajós (Santarém), Óbidos e Tefé, além de outras aldeias missionárias como Surubiú (Alenquer), Jamundás (Faro), Gurupatiba (Monte Alegre), Maturu (Porto de Moz), Vila Bela da Imperatriz (Parintins), Saracá (Silves), Vila de Serpa (Itacotiara), Alvelos (Coari) e Mariuá (Barcelos). Nesse mesmo período foi fundado, em 1669, o Forte de São José do Rio Negro, onde se desenvolveu a aldeia missionária de Manaus. Essas aldeias, segundo Corrêa ${ }^{24}$, constituíram o princípio da formação da rede urbana comandada por Belém, que era o centro de exportação para Lisboa dos produtos colhidos.

A implantação da Companhia Geral do Grão-Pará e Maranhão (1755) trouxe relativo desenvolvimento para a rede urbana amazônica, até então embrionária, decorrente não da incorporação de novas áreas à economia colonial e o consequente aparecimento de novos núcleos dotados de funções urbanas, mas sim da expansão das atividades produtivas nas áreas já incorporadas economicamente.

A política do Marquês de Pombal (1750-1780) de inserir, de modo mais expressivo, a economia amazônica no mercado mundial, afetando a rede urbana, seguiu esses acontecimentos: 1) transferência, já em 1751, da capital do Estado de Grão-Pará e Maranhão, de São Luiz para Belém, ocorrendo em 1772 a separação dos dois Estados; 2) imposição do fim do poder eclesiástico e concessão de liberdade aos índios; 3) doação de sesmarias para colonos e soldados para que cultivassem a terra; 4) introdução, a partir de 1756, de escravos africanos para os cultivos comerciais que são incentivados pela empresa monopolista; 5) expansão dos cultivos de cacau, café, fumo e outros produtos, bem como se verifica a intensificação do extrativismo vegetal e da pecuária; 6) ampliação das importações de produtos manufaturados europeus; 7) criação e reativação de numerosos fortes visando a proteção da Amazônia contra interesses externos; 8) elevação, entre 1755 e 1760, de 46 aldeias missionárias à categoria de vila (entre essas, Tefé, Itacoatiara e Parintins); 9) criação em 1755 da

24. Idem, Ibidem. 
Capitania de São José do Rio Negro, base local no Estado do Amazonas, com capital em Barcelos.

As implicações decorrentes das ações da Companhia especializaram-se de forma desigual criando diferenciação entre os núcleos de povoamento. Surge a hierarquia político-administrativa (em cada uma das duas capitanias passa a existir uma capital, várias vilas e numerosos povoados) em cujo topo situa-se Belém.

Contudo, a estagnação econômica e regional, entre o final do século XVII e a primeira metade do século XIX, afetou a rede urbana amazônica. Dois eventos apresentam-se como os principais responsáveis: a extinção em 1778 da Companhia Geral do Grão-Pará e Maranhão e o fato do panorama mundial não favorecer mais os produtos tropicais em geral.

Entre 1850 e 1920 a rede urbana amazônica ganha nova dimensão tanto econômica quanto social decorrente do boom do extrativismo da borracha, revigorando a economia e a rede urbana. O aumento da produção da borracha baseada no extrativismo amplia a área ocupada, gerando a necessidade de novos núcleos urbanos, e os já existentes são revigorados, em consequência, também, da revalorização econômica de suas respectivas hinterlândias. Esse processo intensifica as relações entre os núcleos de povoamento resultantes da circulação mais intensa de mercadorias que circulavam pela densa rede fluvial amazônica. A acumulação de excedente do sistema de "aviamento", mecanismo básico da circulação de mercadorias nesse período, e a consequente concentração de poder político refletiram no investimento nas cidades de Manaus e Belém, tanto por parte do Estado como de capitais privados, em obras de melhoramentos urbanos.

Nesse período, a Vila de Serpa e a Vila Bela de Imperatriz são elevadas à categoria de cidades, tornando-se Itacoatiara e Parintins, respectivamente. As duas cidades se modernizam graças aos investimentos propiciados pelo desenvolvimento da economia do látex, destacando-se pelo crescimento populacional e por suas economias. Em Itacoatiara, segundo C. Oliveira ${ }^{25}$, um dos fatores dessa modernização na cidade é a implantação de sua alfândega em 1872, criada para reforçar a política de autonomia empregada pelo Amazonas a fim de sair da dependência do Pará, tornando esta um dos centros exportadores de borracha do Estado, vinda dos mais distantes seringais, especialmente do rio Madeira e região.

25 OLIVEIRA, C. Urbanização no Médio Amazonas: A importância de Itacoatiara (AM) como cidade intermediária. Dissertação (Mestrado em Sociedade e Cultura da Amazônia). Programa de Pós-graduação em Sociedade e Cultura na Amazônia, Universidade Federal do Amazonas, Manaus, 2007. 
A segunda estagnação econômica da Amazônia é resultante da decadência da borracha na região. Com a retirada de sementes e mudas de seringueiras na década de 1880 e disseminadas em toda Ásia quente e úmida, a borracha brasileira ganha concorrência no mercado mundial, sendo no período entre 1911 e 1920 ultrapassada pela produção asiática.

A estagnação resulta na diminuição do afluxo migratório para a Amazônia, assim como a existência de certo refluxo para as áreas de origem. Uma das consequências desse processo é a diminuição absoluta da população das pequenas cidades. No entanto, nesse período, alguns dos pequenos núcleos urbanos apresentaram crescimento importante, que por fatores presentes em sua área de influência apresentaram certo dinamismo.

Um dos exemplos que se destaca são as cidades no rio Amazonas "revalorizadas a partir de 1935, aproximadamente, pela introdução e difusão, pelos japoneses, da cultura da juta praticada nas várzeas do Amazonas no trecho entre Manaus e Santarém"26. O ciclo econômico da juta ${ }^{27}$ tem seu início no município de Parintins, ampliando o cultivo posteriormente para outros municípios do Amazonas e do Pará. A cidade de Itacoatiara também participará de maneira significativa nesse ciclo que se estende de 1932 à primeira metade da década de 1980.

A história da juta em Parintins inicia-se com a chegada de uma missão, chefiada pelo deputado, Dr. Tsukasa Uetsuka, vindo do Japão, com a finalidade de escolher um local no município destinado a instalação do núcleo de Kotakuseis (como eram chamados os alunos diplomados pela Escola Superior de Colonização do Japão).

Em 1930, o então ministro da Agricultura do Japão, Dr. Uetsuka, cria o Instituto Amazônia, e recebe permissão do Governo Federal para fundar em Parintins o Instituto de Estudos Agrícolas para Imigração Japonesa, localizado onde hoje é a Vila Amazônia, zona rural do município próximo à cidade ${ }^{28}$.

26 CORRÊA, R. A periodização da rede urbana na Amazônia, op. cit., p. 55.

27 A juta é uma fibra têxtil vegetal que cresce em climas úmidos e tropicais. Tem sua origem na Índia, mas prefere-se atribuir a origem da Corchorus Capsulares à região Indo-Burmânica, no Sudeste da Ásia, enquanto outra espécie, a Corchorus Olitorius é originária do Kordofan, no Sudão anglo-egípcio. Entretanto, a juta encontrou região privilegiada na bacia do rio Gânges, na Índia, onde foi cultivada originalmente no ano de 1837. No Brasil, em especial no Amazonas, ela foi a matéria-prima para a produção de sacarias para o café antes do surgimento do polipropileno (sacarias de plástico), uma das causas principais para o declínio desse ciclo econômico.

28 ROSAL, E. Uma análise sobre o ciclo da juta no município de Parintins. Monografia de conclusão de curso. Faculdade de Estudos Sociais, Universidade Federal do Amazonas, Manaus, 2ooo. 
O Instituto tinha como objetivo desenvolver a cultura da juta na região, mas devido ao fato de a fibra não ser nativa, com sementes vindas da Índia, as primeiras experiências tiveram resultado negativo. Mas nos anos de 1934 e 1935 o colono e técnico agrícola Ryota Oyama conseguiu, por meio de uma série de testes, produzir sementes de juta adaptadas à região e semelhantes às indianas. A partir daí o cultivo da juta ganhou interesse não somente dos colonos japoneses, mas também dos ribeirinhos e se tornaria a principal atividade econômica no rio Amazonas nesse período.

Na década de 1930 na cidade de Parintins havia duas unidades prensadoras instaladas, a Brasmentol Caçapava e a Companhia Têxtil do Castanhal, que trabalhavam no processo de enfardamento da fibra da juta apertando-a em feixes a amarrando-as em fardos de 50 quilos. Parte da produção era exportada para as indústrias de Manaus ou exterior e outra parte vendida para a indústria local. A Companhia Fabriljuta de Parintins existia desde 1932 e era a indústria de beneficiamento da cidade a qual produzia sacarias, telas, fios de aniagem, tapetes e outros. No ano de 1964, Parintins movimentava nos seus portos cerca de 1/3 a 1/4 da produção estadual de fibra de juta ${ }^{29}$.

Em Itacoatiara, o cultivo da juta inicia-se em 1950, uma década após as fábricas I. B. Sabbá \& Cia, Chibly Abrahim \& Cia, Cooperativa Mista de Itacoatiara e Companhia Brasileira de Fiação e Tecelagem de Juta (Brasiljuta) passarem a funcionar, trabalhando tanto no processo de enfardamento da fibra em feixes quanto no seu beneficiamento em sacarias. Assim como em Parintins, em Itacoatiara a juta representou o fortalecimento de sua economia pós-declínio da economia da borracha ${ }^{30}$. Deste modo, as fábricas destas cidades captavam a maior parte da produção de juta dos municípios circunvizinhos e o produto beneficiado era revendido para Manaus e Centro-Sul do país. Para a rede urbana desse período, o ciclo da juta consolidou a representatividade econômica das duas cidades em relação às demais de sua rede e dinamizou o intercâmbio comercial com a capital do estado.

O município de Itacoatiara, no início da década de 1970, retoma o caminho do desenvolvimento, pois já nesse período, a economia da juta dava sinais de declínio. A parceria entre o Estado, com os incentivos fiscais disponibilizados da Superintendência da Zona Franca de Manaus (Suframa), e capital privado promove a instalação das unidades

29 Idem, Ibidem.

3o OLIVEIRA, C. Urbanização no Médio Amazonas: A importância de Itacoatiara (AM) como cidade intermediária, op. cit. 
industriais madeireiras, sendo a cidade eleita, posteriormente, pelo Estado, como novo polo madeireiro na Amazônia Brasileira. Nessa década, Itacoatiara tem o maior crescimento demográfico de sua história, ocorrendo no início da década de 1980 a inversão populacional, possuindo a cidade mais habitantes que o campo (Gráfico 01). Contudo, no final da década de 1980 e início de 1990, as atividades industriais madeireiras começavam um período de crise, Oliveira, ${ }^{31}$ destaca três fatores que contribuíram para esse processo: 1) a discussão acerca da Constituição de 1988, que ameaçava a manutenção da Suframa; 2) a recessão da economia brasileira; 3) mudanças sofridas que permitiam a abertura do mercado nacional à concorrência externa no início da década de 1990.

Como reflexo da crise grandes empresas foram vendidas ou fecharam como a Carolina Indústria e Comércio de Madeiras Tropicais S/A e a Gethal Amazonas S/A. Em 1997, o município esboça possível sinal de mudança com a criação do Polo Moveleiro, mas sem grande resposta o ano de 2000 marca o fim dessa economia.

Em 1995 na parceria entre o governo do estado e o mato-grossense Grupo André Maggi criou-se o Terminal Portuário Privativo Misto de Itacoatiara (TPPMI). O objetivo do terminal era a redução dos custos de transporte da soja do Mato Grosso, até então feito pelos portos de Paranaguá (Paraná) ou Santos (São Paulo). A soja sai da região da chapada dos Parecis até o Terminal Graneleiro de Porto Velho (Rondônia), daí é embarcada em balsas que fazem o percurso até Itacoatiara pela hidrovia Madeira-Amazonas. A posição estratégica do terminal em Itacoatiara possibilita maior facilidade de escoamento da produção da soja para os Estados Unidos e reduz o percurso para a África e Europa.

Para o município de Itacoatiara o terminal trouxe desenvolvimento em diversos setores, a saber: 1) incentivos no agronegócio pelo Grupo André Maggi, por meio da empresa Agropecuária Jesuíta Ltda., mediante o arrendamento de terras em suas três fazendas no município, para o cultivo rotativo de arroz e soja, o beneficiamento é feito pela própria empresa e comercializado em Itacoatiara e Manaus; 2) os empregos diretos e indiretos produzidos pelas empresas que compõem o holding do Grupo André Maggi; 3) o alto volume de exportação das empresas que utilizam o terminal, como Amaggi Exportação Importação Ltda., Bunge Alimentos S/A e Agrícola e Pecuária Morro Azul Ltda. ${ }^{32}$.

Em Parintins, o ano de 1975 marca a chegada do município ao topo no ranking do efetivo de rebanho bovino no estado do Amazonas,

31 Idem, Ibidem.

32 Idem, Ibidem. 
após esse ano até 2008, o município oscila entre a primeira e a terceira posição segundo o Censo Agropecuário 1974-2008 do IBGE. A agropecuária cresceu de modo bastante significativo em Parintins, sendo esta uma das principais atividades econômicas.

A década de 1980 marca o declínio da economia da juta em Parintins com a falência em 1984 da principal fábrica desse setor na cidade, a Companhia Fabriljuta de Parintins. Os custos de produção cresciam nas indústrias do Amazonas, enquanto a capacidade de absorção do mercado consumidor se reduzia. Rosal ${ }^{33}$ identifica três fatores que foram responsáveis por isso: 1) trabalho em regime de expressiva capacidade ociosa e dificuldades no capital de giro das fábricas; 2) surgimento do concorrente polipropileno na produção de sacarias em plástico; 3) queda das vendas de sacas para o café devido à diminuição da exportação deste.

Em decorrência desse fato há a inversão populacional no município, a cidade, pela primeira vez, concentra mais habitantes que o campo (Gráfico 02). Desde então esta realidade se mantém: o esvaziamento da área rural do município e o crescimento populacional da cidade. Contudo, nessa mesma década surge uma nova atividade econômica a revigorar o município no pós-declínio da economia da juta. O Festival Folclórico do Boi-bumbá de Parintins ganha fôlego nesse período, sendo a principal atividade econômica da cidade, tornando-a conhecida nacional e internacionalmente.

A periodização da rede urbana das cidades de Itacoatiara e Parintins vem fortalecer a representatividade e a importância desses dois centros urbanos para o Amazonas desde o século XVII. No período atual, o setor de serviços, em especial o ensino superior, apresenta-se como o dínamo a redefinir o papel nas cidades médias brasileiras e para as duas cidades não é diferente.

As cidades médias, desde meados do século XIX, tinham papéis definidos, em grande parte, pela situação geográfica que ocupavam e/ ou papéis político-administrativos que desempenhavam. Assim, a relevância da cidade média tinha, e ainda tem, relação direta com a área em que exercia influência. Se antes a área de influência era determinada pela distância que as pessoas estavam dispostas a percorrer para adquirir bens e serviços de uma cidade média, essa área de influência, atualmente, é caracterizada, sobretudo, por articulações espaciais que não dependem mais da continuidade territorial ${ }^{34}$.

33 ROSAL, E. Uma análise sobre o ciclo da juta no município de Parintins, op. cit.

34 SPOSITO, M.; ELIAS, D.; SOARES, B.; MAIA, D.; GOMES, E. O estudo das cidades médias brasileiras: uma proposta metodológica. In: SPOSITO, M. (Org.). Cidades 
Apesar de tradicionalmente considerarem-se as atividades econômicas do setor primário e secundário como os principais agentes do desenvolvimento, elas sofrem uma mudança radical na Amazônia a partir da década de 1990, assim como um crescimento da importância do setor terciário, de serviços. Sem dúvida, em muitas cidades, a principal economia é a do "colarinho branco" ou como se costuma dizer no Amazonas "do contracheque" dos funcionários públicos (de todas as esferas) e dos militares. Neste contexto, ao se analisar o espaço intra e interurbano dessas duas cidades, Itacoatiara e Parintins, pode-se perceber um novo e importante elemento na dinâmica econômica e populacional relacionada ao setor de serviços: o ensino superior.

Em trabalho anterior ${ }^{35}$, referente à segregação socioespacial na cidade de Parintins, identificou-se as possíveis causas de migração dos chefes de domicílio dos bairros que correspondiam à área de expansão da cidade (bairros de Itaúna I, II e Paulo Corrêa) e identificou-se que a busca por educação era maior do que a busca por emprego. A busca por educação estava direcionada para os filhos já numa expectativa do ingresso destes no ensino superior disponibilizado na cidade, redefinindo o papel do ensino na constituição da rede urbana no Amazonas.

\section{A dinâmica urbana e o ensino público superior}

O ensino superior é interiorizado na década de 1970 em Parintins e na década de 1980 em Itacoatiara com a instalação de universidades públicas, vindas de outros estados, para firmar polos nessas cidades, destacando o início do ensino público superior nos municípios no interior do Amazonas. Segundo J. Oliveira ${ }^{36}$, em Itacoatiara a primeira experiência que se tem anterior à instalação da Universidade Federal do Amazonas (UFAM) e da Universidade do Estado do Amazonas (UEA) é com a Universidade Estadual Paulista (Unesp - Rio Claro), no início da década de 1980, com a disponibilização de cursos de licenciatura, como o de Licenciatura Curta em Geografia, que eram ministrados por módulos

médias: espaços em transição. São Paulo: Expressão Popular, 2007, p. 35-67.

35 MARINHO, T.; SCHOR, T. Segregação socioespacial, dinâmica populacional e rede urbana na cidade de Parintins (AM). Geografares - Revista do Departamento de Geografia da Ufes, n. 7, v. 6, p. 77-92, 2009.

36 OLIVEIRA, J. História da implantação das universidades públicas nas cidades de Parintins e Itacoatiara. Entrevista realizada por Thiago Pimentel Marinho. Manaus, 22 jan. 2010. 
no período do recesso escolar, sem quadro fixo de professores e funcionários instalados no município.

Em Parintins a implantação da primeira universidade foi mais sistematizada afirma J. Oliveira ${ }^{37}$. Diferentemente de Itacoatiara, a cidade possuía de forma mais consolidada a instalação de uma universidade pública, a Universidade do Estado do Rio de Janeiro (Uerj), que durante toda a década de 1970 possuía um campus avançado, mantido pelo Projeto Rondon, ligado ao Ministério do Interior, com atividades permanentes, disponibilizando uma série de cursos e realizando diversos serviços na área de saúde, em especial odontologia, tanto na cidade quanto em comunidades rurais próximas à sede municipal.

No início da década de 1980, questões econômicas impossibilitaram a permanência do campus da Uerj no município, sendo sua sede repassada para a UFAM que só iniciará suas atividades efetivas em Parintins a partir de 1988, sendo o curso de Licenciatura em Letras o primeiro a ser disponibilizado. No período da administração do reitor Marcos Barros (1988-1991) foram realizados concursos para os cursos de Física, Química e Matemática, desta forma, esses deixaram de ser disponibilizados somente no período de férias para serem oferecidos no período letivo, com a criação de um quadro qualificado de profissionais para a cidade. O curso de Geografia teve seu início em 1989, mantido no período de férias acadêmicas e criou-se também naquele ano o curso de Administração de forma contínua ${ }^{38}$.

Após esse período há a efetiva consolidação do ensino superior nas duas cidades. Em 2001 é criada a UEA e instalados os Centros de Estudos Superiores em Itacoatiara e em Parintins. A UFAM consolidará a sua interiorização a partir de 2007, instalando o Instituto de Ciências Exatas e Tecnologia em Itacoatiara e o Instituto de Ciências Sociais, Educação e Zootecnia em Parintins. Nas duas cidades há presença significativa de alunos dos mais diversos municípios do Amazonas e do Pará, no caso de Parintins.

Com o intuito de compreender-se o processo de migração criado pela introdução do ensino público superior nas duas cidades, realizaram-se idas a campo no mês de março de 2010, na cidade de Itacoatiara, e no mês de maio de 2010, na cidade de Parintins, a fim de aplicar questionários com os alunos da Universidade Federal do

37 Idem, Ibidem.

38 OLIVEIRA, J. História da implantação das universidades públicas nas cidades de Parintins e Itacoatiara, op. cit. 
Amazonas e Universidade do Estado do Amazonas que se deslocaram para Itacoatiara ou Parintins porque passaram no vestibular.

O objetivo era aplicar o questionário com o maior número de alunos que se enquadravam na situação proposta pela pesquisa. Assim, o universo de análise integrou 186 alunos em Itacoatiara, sendo 112 na UFAM, 74 na UEA e 221 alunos em Parintins, sendo oitenta na UFAM e 141 na UEA. Devido aos mais diversos motivos, nem todos os cursos oferecidos pelas universidades nas duas cidades foram contemplados na pesquisa, assim como o total de alunos migrantes, mas estima-se que foram aplicados os questionários com 70\% dos alunos inseridos no objetivo da pesquisa.

As perguntas tinham o intuito de identificar a origem dos alunos migrantes, a intensidade por município, a dinâmica de migração pendular e o fluxo futuro, a partir do questionamento sobre onde o aluno pretende trabalhar após a conclusão do curso, e se o fluxo poderia variar o destino por cidade (Parintins e Itacoatiara), por universidade (UFAM e UEA) e por curso disponibilizado.

Em Itacoatiara, Manaus se apresenta como principal município da qual migram alunos, contudo apresenta número maior de municípios atendidos pelas duas universidades (Figura 03).

Em Parintins, o município de Barreirinha destaca-se com o maior número de alunos do quadro de migrantes e atende mais alunos vindos das suas zonas rurais. Os alunos quando questionados sobre o fluxo futuro (tendo como opção seu município, Manaus e outro município) afirmaram os seus municípios de origem como o principal destino (quadro esse que se apresenta nas duas universidades e nas duas cidades), seguido de Manaus, Itacoatiara e/ou Parintins (Figura 04).

Apesar da continuidade em termos de importância na rede urbana, a re-estruturação das funções urbanas devido às novas atividades, neste caso o impacto do estabelecimento do ensino público superior em ambas, redefine a maneira pela qual podemos ler a periodização e a rede urbana no Baixo Amazonas. Uma primeira consideração é que diferentemente dos outros ciclos econômicos que impactavam as cidades de forma indireta, pois grande parte da renda e riqueza gerada era acumulada fora da região, o ensino superior impacta de forma direta, posto que forma pessoas que são da cidade e/ou região e que têm a intenção de lá permanecer. A riqueza, neste contexto como consolidação de processos de conhecimento, tende a permanecer no local. A transformação da cidade em prestadora de serviço qualificado implica em diversas transformações na estrutura urbana como o surgimento de pensões, restaurantes e, no caso de Parintins, a formação de um novo bairro de classe média no qual os 
professores recém-contratados se mobilizam para construir suas moradias. É importante salientar que com o ensino superior tem-se não só uma migração de estudantes, mas também de funcionários e professores com demandas por outros serviços, como lojas e supermercados com produtos mais sofisticados tais como equipamentos eletrônicos. Com a UEA, ambas as cidades receberam um acesso melhor à rede internacional de computadores possibilitando a existência de vários cursos à distância e o programa de "tele-medicina", impactando um conjunto ainda maior da população.

Uma segunda consideração diz respeito à forma de representar a rede urbana. No artigo de Corrêa, supracitado, a rede urbana no Amazonas é descrita como dendrítica. A análise da rede a partir do ensino superior mostra-nos outra figura muito mais complexa e menos centralizada em Manaus. Os resultados nos mostram duas redes urbanas distintas. A cidade de Itacoatiara que mantém um forte vínculo com Manaus e a de Parintins que organiza sua região de influência. Ambas as redes não convergem e pouco se comunicam. Apesar de ambas as cidades estarem localizadas na margem esquerda do rio Amazonas, elas não mantêm entre si relações. Itacoatiara exerce função clássica de cidade média como intermediária a Manaus, em termos de ensino superior recebe alunos de todas as partes do estado do Amazonas, principalmente de Manaus. Parintins recebe das cidades de seu entorno, mostrando que a tipologia proposta por nós em estudos anteriores é insuficiente para compreender a complexidade de Parintins. Não basta analisá-la como cidade média de "dinâmica econômica externa", pois além desta característica, os dados obtidos que refletem a concentração de alunos vindos dos municípios do entorno, revelam que Parintins é também uma cidade de responsabilidade territorial.

\section{Considerações}

As cidades de Itacoatiara e Parintins desde o início da rede urbana na Amazônia já se destacavam pelos seus papéis empregados nesta, em especial do Amazonas. Ambas surgem como aldeias missionárias que com os fortins eram a base do comércio das "drogas do sertão" no período que se estende da metade do século XVII ao final da primeira metade do século XVIII. Com a implantação da Companhia Geral do Grão-Pará e Maranhão, a rede urbana se desenvolve, decorrente não da incorporação de novas áreas à economia colonial e o consequente aparecimento de novos núcleos dotados de funções urbanas, mas sim da expansão das 
atividades produtivas nas áreas já incorporadas economicamente. Isso pode ser exemplificado com uma das políticas instituídas pelo governo do Marquês de Pombal após a implantação da Companhia que foi a elevação de 46 aldeias missionárias à categoria de vilas, no período de 1755 e 1760, entre elas Itacoatiara e Parintins.

No período de estagnação econômica decorrente do declínio da borracha, as duas cidades desenvolvem, a partir de 1930 a 1980, a economia da juta, sendo Parintins, nesse período, uma das principais sedes nacionais dessa economia. Atualmente, em Itacoatiara, o Terminal Privativo Misto de Itacoatiara, criado em 1995, é base para escoamento da produção de soja do Mato Grosso, pois a posição estratégica do terminal possibilita maior facilidade de escoamento da produção da soja para os Estados Unidos e reduz o percurso para a África e Europa. Aliado ao terminal a cidade também há uma grande atividade cultural a nível regional, o Festival da Canção de Itacoatiara (Fecani). Em Parintins, desde a década de 1970, é um dos maiores produtores de gado bovino do estado. Mas é a partir do Festival Folclórico do Boi-bumbá que a cidade se torna conhecida em todo o Brasil e no exterior, promovendo o maior evento folclórico do país. A implantação do ensino superior nas cidades de Parintins e Itacoatiara reafirma e fortalece junto com outros elementos histórico-geográficos, econômicos e culturais a importância delas na manutenção da rede urbana do Amazonas.

Este estudo demonstra a necessidade de uma análise multiescalar intra e interurbana para se compreender a rede urbana no Amazonas. A localização geográfica, ainda importante na escala da Amazônia, não é definidora da rede urbana. A complexidade do urbano no Amazonas revela dinâmicas urbanas que superam sua localidade tal como é o caso para as cidades de Itacoatiara e Parintins, ambas localizadas ao longo da calha do mesmo rio, porém em redes urbanas distintas. Além de que devido às dimensões de seu território (gigantesco) e de suas cidades (diminutas quando comparadas aos rios e à floresta), a escala nacional não dá conta de entender o regional e a escala do local não permite voltar à discussão do nacional, por isso é importante navegar por uma proposta multiescalar, neste caso o da rede urbana, que ponha em diálogo o local com o nacional sem perder de vista a imensidão da floresta e dos rios. 


\section{Sobre os autores}

\section{Tatiana Schor}

Professora no Departamento de Geografia da Universidade Federal do Amazonas (UFAM, Manaus, AM, Brasil).

E-mail: tatiana.schor@gmail.com

\section{Thiago Pimentel Marinho}

Mestrando do Programa de Pós-graduação de Geografia da Universidade Federal do Amazonas (UFAM, Manaus, AM, Brasil). Bolsista de Desenvolvimento Tecnológico Industrial do CNPq - Nível C.

E-mail: thp.marinho@gmail.com

Os resultados apresentados neste artigo são oriundos da pesquisa financiada pela Fundação de Amparo à Pesquisa do Estado do Amazonas (Fapeam), por meio do Programa Institucional de Bolsas de Iniciação Científica da Universidade Federal do Amazonas (Pibic-Ufam), desenvolvida pelo Núcleo de Estudos e Pesquisas das Cidades da Amazônia Brasileira (Nepecab-Ufam) por meio do projeto "O impacto da consolidação do polo industrial de Manaus nas cidades do Amazonas: o caso de Itacoatiara e Parintins", Edital MCT/CNPq CAPDA; Processo n. 575780/20o8-8. O financiamento e apoio logístico para a realização dos trabalhos de campo nas cidades de Parintins e Itacoatiara contaram com os recursos disponíveis nesse projeto e da Rede de Pesquisadores de Cidades Médias (ReCiMe). 


\begin{tabular}{|c|c|c|}
\hline $\begin{array}{l}\text { Centros } \\
\text { urbanos }\end{array}$ & Características & Subníveis \\
\hline Metrópoles & $\begin{array}{l}\text { São os } 12 \text { principais centros urbanos } \\
\text { do país, que se caracterizam por seu } \\
\text { grande porte e por fortes relaciona- } \\
\text { mentos entre si, além de, em geral, } \\
\text { possuírem extensa área de influ- } \\
\text { ência direta. O conjunto foi dividido } \\
\text { em } 3 \text { subníveis, segundo a extensão } \\
\text { territorial e a intensidade destas } \\
\text { relações. }\end{array}$ & $\begin{array}{l}\text { a. Grande metrópole nacional } \\
\text { - São Paulo, o maior conjunto } \\
\text { urbano do país, com 19,5 } \\
\text { milhões de habitantes, em } 2007, \\
\text { e alocado no primeiro nível da } \\
\text { gestão territorial; } \\
\text { b. Metrópole nacional - Rio } \\
\text { de Janeiro e Brasília, com } \\
\text { população de } 11,8 \text { milhões e } \\
3,2 \text { milhões em } 2007 \text {, respec- } \\
\text { tivamente, também estão no } \\
\text { primeiro nível da gestão territo- } \\
\text { rial. Juntamente com São Paulo, } \\
\text { constituem foco para centros } \\
\text { localizados em todo o país; } \\
\text { c. Metrópole - Manaus, Belém, } \\
\text { Fortaleza, Recife, Salvador, Belo } \\
\text { Horizonte, Curitiba, Goiânia e } \\
\text { Porto Alegre, com população } \\
\text { variando de } 1,6 \text { (Manaus) a } 5,1 \\
\text { milhões (Belo Horizonte), cons- } \\
\text { tituem o segundo nível da gestão } \\
\text { territorial. Note-se que Manaus } \\
\text { e Goiânia, embora estejam no } \\
\text { terceiro nível da gestão terri- } \\
\text { torial, têm porte e projeção } \\
\text { nacional que lhes garantem a } \\
\text { inclusão neste conjunto. }\end{array}$ \\
\hline $\begin{array}{l}\text { Capital } \\
\text { regional }\end{array}$ & $\begin{array}{l}\text { Integram este nível } 70 \text { centros que, } \\
\text { como as metrópoles, também se rela- } \\
\text { cionam com o estrato superior da rede } \\
\text { urbana. Com capacidade de gestão no } \\
\text { nível imediatamente inferior ao das } \\
\text { metrópoles, têm área de influência } \\
\text { de âmbito regional, sendo referidas } \\
\text { como destino, para um conjunto de } \\
\text { atividades, por grande número de } \\
\text { municípios. Como o anterior, este } \\
\text { nível também tem } 3 \text { subdivisões. } \\
\text { O primeiro grupo inclui as capitais } \\
\text { estaduais não classificadas no nível } \\
\text { metropolitano e Campinas. O segundo } \\
\text { e o terceiro, além da diferenciação } \\
\text { de porte, têm padrão de localização } \\
\text { regionalizado, com o segundo mais } \\
\text { presente no Centro-Sul, e o terceiro } \\
\text { nas demais regiões do país. }\end{array}$ & $\begin{array}{l}\text { a. Capital regional A - consti- } \\
\text { tuído por } 11 \text { cidades, com } \\
\text { medianas de } 955 \text { mil habitantes } \\
\text { e } 487 \text { relacionamentos; } \\
\text { b. Capital regional B - consti- } \\
\text { tuído por cidades, com } \\
\text { medianas de } 435 \text { mil habitantes } \\
\text { e } 406 \text { relacionamentos; } \\
\text { c. Capital regional C - consti- } \\
\text { tuído por } 39 \text { cidades com } \\
\text { medianas de } 250 \text { mil habitantes } \\
\text { e } 162 \text { relacionamentos. }\end{array}$ \\
\hline
\end{tabular}




\begin{tabular}{|c|c|c|}
\hline $\begin{array}{c}\text { Centro } \\
\text { sub-regional }\end{array}$ & $\begin{array}{l}\text { Integram este nível } 169 \text { centros } \\
\text { com atividades de gestão menos } \\
\text { complexas, dominantemente entre } \\
\text { os níveis 4 e } 5 \text { da gestão territorial; } \\
\text { têm área de atuação mais redu- } \\
\text { zida, e seus relacionamentos com } \\
\text { centros externos à sua própria } \\
\text { rede dão-se, em geral, apenas com } \\
\text { as } 3 \text { metrópoles nacionais. Com } \\
\text { presença mais adensada nas áreas } \\
\text { de maior ocupação do Nordeste } \\
\text { e do Centro-Sul, e mais esparsa } \\
\text { nos espaços menos densamente } \\
\text { povoados das Regiões Norte e } \\
\text { Centro-Oeste. } \\
\end{array}$ & $\begin{array}{l}\text { a. Centro sub-regional A - } \\
\text { constituído por } 85 \text { cidades, com } \\
\text { medianas de } 95 \text { mil habitantes } \\
\text { e } 112 \text { relacionamentos; } \\
\text { b. Centro sub-regional B - } \\
\text { constituído por } 79 \text { cidades, com } \\
\text { medianas de } 71 \text { mil habitantes } \\
\text { e } 71 \text { relacionamentos. }\end{array}$ \\
\hline $\begin{array}{l}\text { Centro de } \\
\text { Zona }\end{array}$ & $\begin{array}{l}\text { Nível formado por } 556 \text { cidades de } \\
\text { menor porte e com atuação restrita à } \\
\text { sua área imediata; exercem funções } \\
\text { de gestão elementares. }\end{array}$ & $\begin{array}{l}\text { a. Centro de zona A - } 192 \\
\text { cidades, com medianas de } 45 \\
\text { mil habitantes e } 49 \text { relaciona- } \\
\text { mentos. Predominam os níveis } \\
5 \text { e } 6 \text { da gestão territorial (94 e } \\
72 \text { cidades, respectivamente), } \\
\text { com } 9 \text { cidades no quarto nível } \\
\text { e } 16 \text { não classificadas como } \\
\text { centros de gestão; } \\
\text { b. Centro de zona B - } 364 \\
\text { cidades, com medianas de } 23 \\
\text { mil habitantes e } 16 \text { relaciona- } \\
\text { mentos. A maior parte, } 235, \text { não } \\
\text { havia sido classificada como } \\
\text { centro de gestão territorial, e } \\
\text { outras } 107 \text { estavam no último } \\
\text { nível daquela classificação. }\end{array}$ \\
\hline Centro local & $\begin{array}{l}\text { As demais } 4.473 \text { cidades cuja centra- } \\
\text { lidade e atuação não extrapolam os } \\
\text { limites do seu município, servindo } \\
\text { apenas aos seus habitantes, têm } \\
\text { população dominantemente inferior } \\
\text { a } 10 \text { mil habitantes (mediana de } \\
8.133 \text { habitantes). Em relação aos } \\
\text { elementos da análise, os } 802 \text { centros } \\
\text { acima do nível } 5 \text { abrangem } 548 \\
\text { centros de gestão do território e } 254 \\
\text { cidades com centralidade identifi- } \\
\text { cada a partir dos questionários, que } \\
\text { foram incluídas no conjunto final. }\end{array}$ & \\
\hline
\end{tabular}

Fonte: INSTITUTO BRASILEIRO DE GEOGRAFIA E ESTATÍSTICA. Regiões de influência das cidades - 2007. Rio de Janeiro: IBGE, 2008, p. 11-13. 
Tabela o2. Arranjos institucionais.

\begin{tabular}{|c|c|}
\hline Arranjos institucionais & Dados coletados \\
\hline Variáveis históricas & Origem da cidade; mapas históricos; cronologia. \\
\hline $\begin{array}{c}\text { Relações intra e } \\
\text { interurbana }\end{array}$ & $\begin{array}{l}\text { Fluxos migratórios; modos de morar; acesso e } \\
\text { transporte intramunicipal; produção agrícola e } \\
\text { abastecimento da cidade. }\end{array}$ \\
\hline Serviços e comércio & $\begin{array}{l}\text { Telefonia; rádio; antenas de telecomunicações; } \\
\text { provedores de internet; comercialização de } \\
\text { alimentos. }\end{array}$ \\
\hline Arrecadação de impostos & $\begin{array}{l}\text { Cesta de impostos municipais arrecadados (IPTU, } \\
\text { ICMS); repasses recebidos (estadual e federal); } \\
\text { royalties. }\end{array}$ \\
\hline $\begin{array}{l}\text { Insumos para a Cesta } \\
\text { Básica Regionalizada }\end{array}$ & $\begin{array}{l}\text { Cesta básica de alimentação e coleta de preço } \\
\text { dos produtos nas cidades ao longo da calha nos } \\
\text { períodos de seca e cheia, visando elaborar um indi- } \\
\text { cador de preço da cesta básica ao consumidor final. }\end{array}$ \\
\hline Índice de construção civil & $\begin{array}{l}\text { Cesta de insumos para a construção civil (madeira, } \\
\text { areia, seixo, telha, tijolos) com coleta de preços nas } \\
\text { cidades ao longo da calha. }\end{array}$ \\
\hline Produtos extrativistas & $\begin{array}{l}\text { Forma de organização (associação/sindicato); } \\
\text { produção; comercialização e preço dos produtos } \\
\text { extrativistas não madeireiros; cadeias produtivas e } \\
\text { arranjos produtivos locais. }\end{array}$ \\
\hline Infraestrutura urbana & $\begin{array}{l}\text { Dados sobre saúde; educação; segurança pública; } \\
\text { hotelaria; dados relativos à presença de forças } \\
\text { armadas; sistema financeiro; sistema de forneci- } \\
\text { mento de água e energia; saneamento básico. }\end{array}$ \\
\hline Fluxo de transporte & Transporte interurbano e intraurbano. \\
\hline
\end{tabular}

Fonte: OLIVEIRA, J.; SCHOR, T. Urbanização na Amazônia: o local e o global. In: VAL, A.; SANTOS, G. (Orgs.). Caderno de Debates. Manaus: Grupo de Estudos Estratégicos Amazônicos / INPA, t. III, p. 145-189, 2010, p. $15^{2}$. 
Tabela oz. Classificação e Tipificação Urbana - Cidades da Calha Solimões-Amazonas.

\begin{tabular}{|c|c|c|}
\hline Tipologia & Características & Cidades \\
\hline $\begin{array}{l}\text { Cidade } \\
\text { média de } \\
\text { responsa- } \\
\text { bilidade } \\
\text { territorial }\end{array}$ & $\begin{array}{l}\text { Exerce função na rede que vai além das suas } \\
\text { características em si, pois detém responsa- } \\
\text { bilidade territorial que a torna um nódulo } \\
\text { importante internamente na rede. Exerce } \\
\text { diversas funções urbanas e contém arranjos } \\
\text { institucionais que são importantes não só } \\
\text { para o município, mas para as cidades e } \\
\text { municípios ao seu redor. A importância } \\
\text { territorial da cidade tem origem no desenvol- } \\
\text { vimento histórico-geográfico que constitui } \\
\text { a rede urbana nessa região. Seu desenvol- } \\
\text { vimento econômico tende a agregar valor à } \\
\text { região. Ainda nesta tipologia, deve-se incluir } \\
\text { a variável "de fronteira", pois a dinâmica das } \\
\text { cidades localizadas na fronteira as diferencia } \\
\text { das demais, tanto em termos de perfil urbano } \\
\text { dentro da rede da qual participam, princi- } \\
\text { palmente por conta do papel exercido pelas } \\
\text { forças armadas e populações indígenas, como } \\
\text { também com relação às redes que se estabe- } \\
\text { lecem internacionalmente. }\end{array}$ & $\begin{array}{c}\text { Tabatinga; } \\
\text { Tefé }\end{array}$ \\
\hline $\begin{array}{l}\text { Cidade } \\
\text { média com } \\
\text { dinâmica } \\
\text { econômica } \\
\text { externa }\end{array}$ & $\begin{array}{l}\text { Tem importância na rede por sua inserção } \\
\text { em uma dinâmica econômica externa. Os } \\
\text { vínculos com as demais cidades da rede não } \\
\text { são necessariamente fortes, nem seu desen- } \\
\text { volvimento econômico implicará em um } \\
\text { desenvolvimento regional significativo, pois } \\
\text { a atividade econômica responsável pelo seu } \\
\text { desenvolvimento não agrega valor nem no } \\
\text { local nem regionalmente. }\end{array}$ & $\begin{array}{c}\text { Coari; } \\
\text { Parintins }\end{array}$ \\
\hline $\begin{array}{l}\text { Cidade } \\
\text { média com } \\
\text { função de } \\
\text { intermedi- } \\
\quad \text { ária }\end{array}$ & $\begin{array}{l}\text { Por conta da proximidade com a metrópole } \\
\text { regional e da ligação rodoviária, exerce } \\
\text { função de intermediária entre as demais } \\
\text { cidades e redes urbanas com Manaus, } \\
\text { abastecendo e sendo abastecida por Manaus. }\end{array}$ & $\begin{array}{c}\text { Manacapuru; } \\
\text { Itacoatiara }\end{array}$ \\
\hline
\end{tabular}




\begin{tabular}{|c|c|c|}
\hline $\begin{array}{c}\text { Cidades } \\
\text { pequenas }\end{array}$ & Características & Cidades \\
\hline $\begin{array}{l}\text { Cidade } \\
\text { pequena } \\
\text { de respon- } \\
\text { sabilidade } \\
\text { territorial }\end{array}$ & $\begin{array}{l}\text { Tal qual as demais cidades de } \\
\text { responsabilidade territorial, desempenha um } \\
\text { papel importante na manutenção da rede em } \\
\text { uma escala diferenciada. Exerce uma função } \\
\text { intermediária nos fluxos de transporte e } \\
\text { comercialização, entre as cidades médias e } \\
\text { as demais cidades pequenas e aglomerados } \\
\text { humanos. Tem um relevante papel na } \\
\text { organização das diversas etnias que habitam } \\
\text { e se deslocam pela região do Alto Solimões. } \\
\text { Transforma-se em nódulo nas diversas } \\
\text { redes que perpassam territórios indígenas. } \\
\text { Também nesta tipologia, deve-se incluir } \\
\text { a variável de "fronteira", pois tais cidades } \\
\text { exercem um papel específico e constituem } \\
\text { redes de relações próprias de abrangência } \\
\text { internacional. }\end{array}$ & $\begin{array}{c}\text { Bejamin } \\
\text { Constant; } \\
\text { Fonte Boa; } \\
\text { Santo Antônio } \\
\text { do Içá }\end{array}$ \\
\hline $\begin{array}{l}\text { Cidade } \\
\text { pequena } \\
\text { com } \\
\text { dinâmica } \\
\text { econômica } \\
\text { externa }\end{array}$ & $\begin{array}{l}\text { Tem sua economia voltada para exportação } \\
\text { de algum produto (mineral, agropecuário, } \\
\text { extrativista, ou de pequena indústria) para a } \\
\text { cidade de porte grande, neste caso Manaus. } \\
\text { É pouco relevante na manutenção da rede } \\
\text { urbana da calha. }\end{array}$ & $\begin{array}{l}\text { Iranduba; } \\
\text { Codajás; } \\
\text { Carreiro da } \\
\text { Várzea }\end{array}$ \\
\hline $\begin{array}{c}\text { Cidade } \\
\text { especial }\end{array}$ & $\begin{array}{l}\text { Devido à ausência de infraestrutura que } \\
\text { possibilite o pleno exercício das funções } \\
\text { urbanas e à localização geográfica que torna } \\
\text { mais complicada sua relação com a calha } \\
\text { central do rio, torna-se dependente das } \\
\text { cidades médias e pequenas de responsabili- } \\
\text { dade territorial. }\end{array}$ & $\begin{array}{c}\text { Amaturá; } \\
\text { Alvarães; } \\
\text { Santo Antônio } \\
\text { do Iça; Uarini; } \\
\text { Anori; } \\
\text { Tonantins; } \\
\text { Silves; } \\
\text { Uricurituba; } \\
\text { Anamã; Jutaí; } \\
\text { São Paulo } \\
\text { de Olivença; } \\
\text { Urucará }\end{array}$ \\
\hline
\end{tabular}

Fonte: OLIVEIRA, J.; SCHOR, T. Urbanização na Amazônia: o local e o global, op. cit., p. 154-155. 


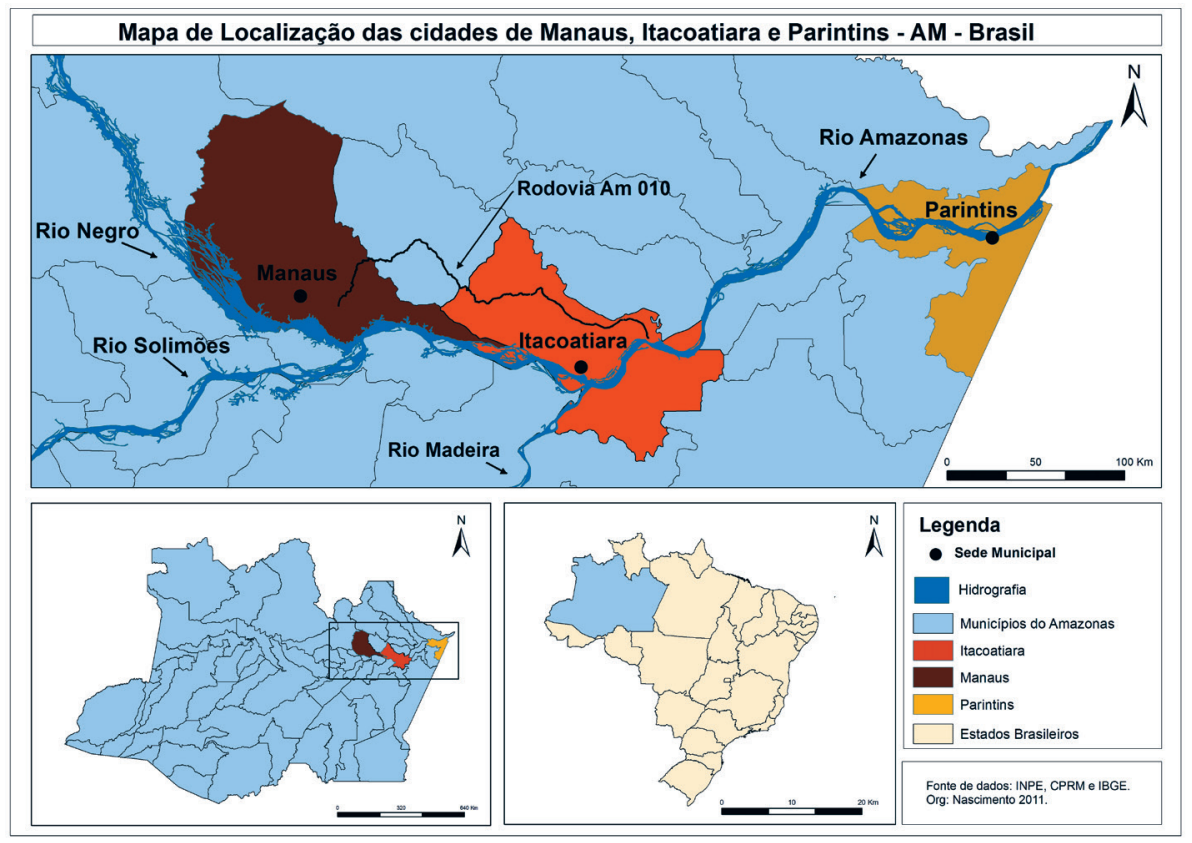

Figura 01. Mapa de localização das cidades de Manaus, Itacoatiara e Parintins (AM). Fonte: Acervo Nepecab, 2011.

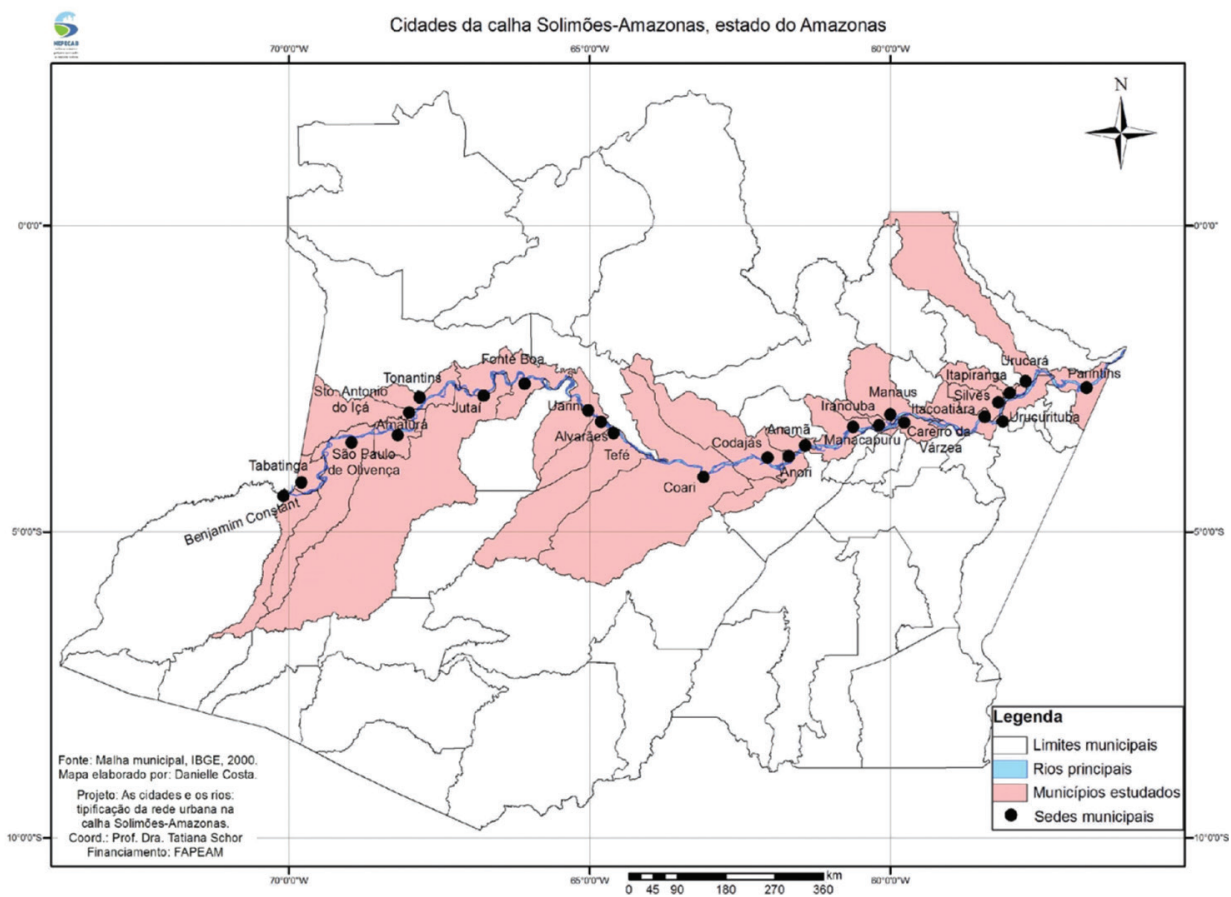

Figura 02. Cidades da calha do rio Solimões-Amazonas (AM). Fonte: Acervo Nepecab, 2008. 


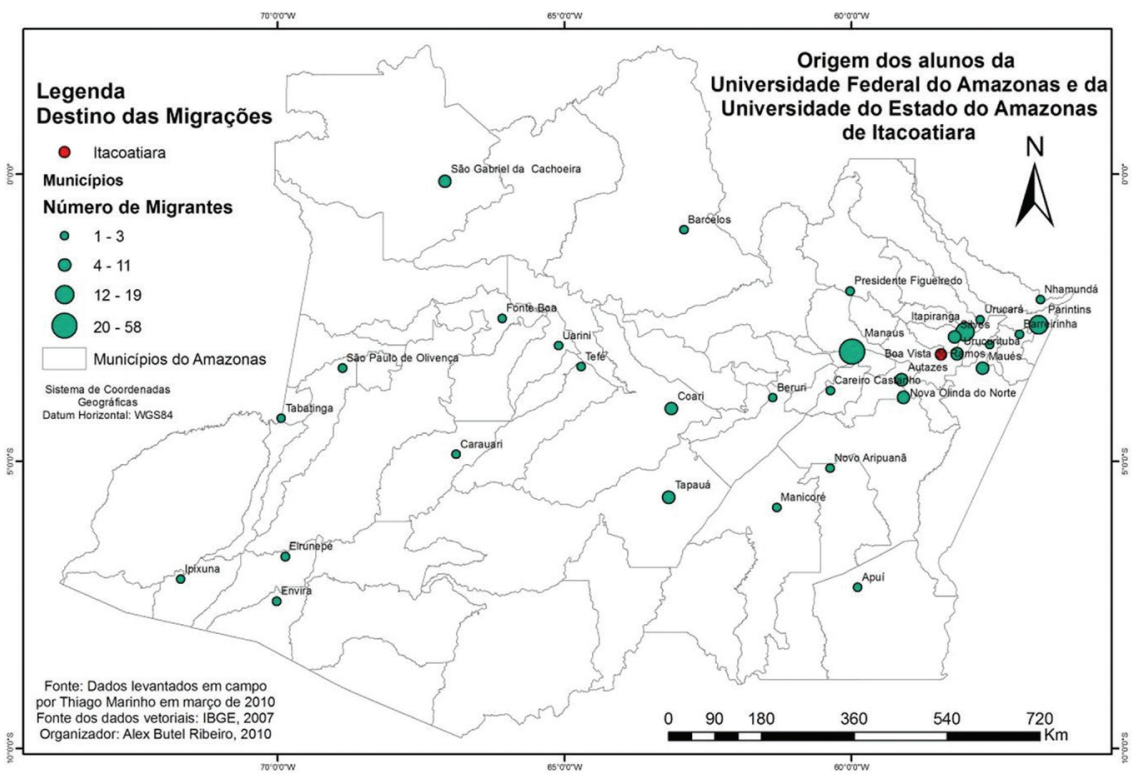

Figura 03. Origem dos alunos da UFAM e UEA de Itacoatiara.

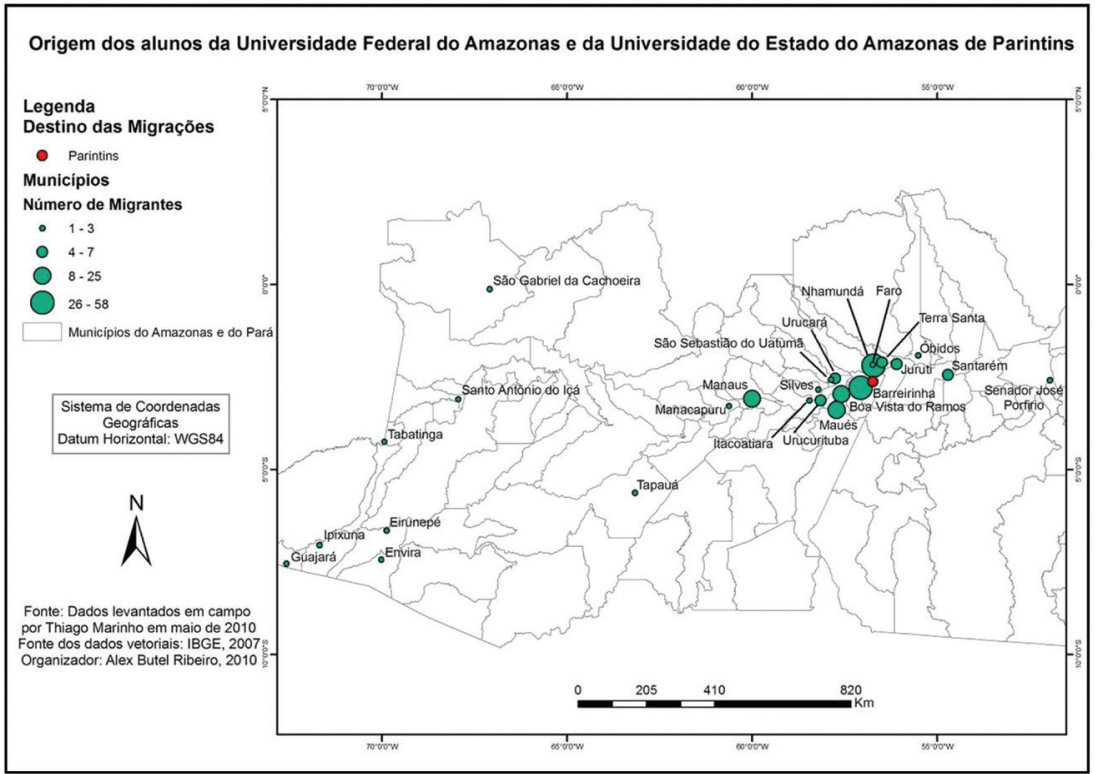

Figura 04. Origem dos alunos da UFAM e UEA de Parintins.

Fonte: Acervo Nepecab, 2010.

Tabela o1. Hierarquia dos centros urbanos brasileiros (IBGE-2007). 


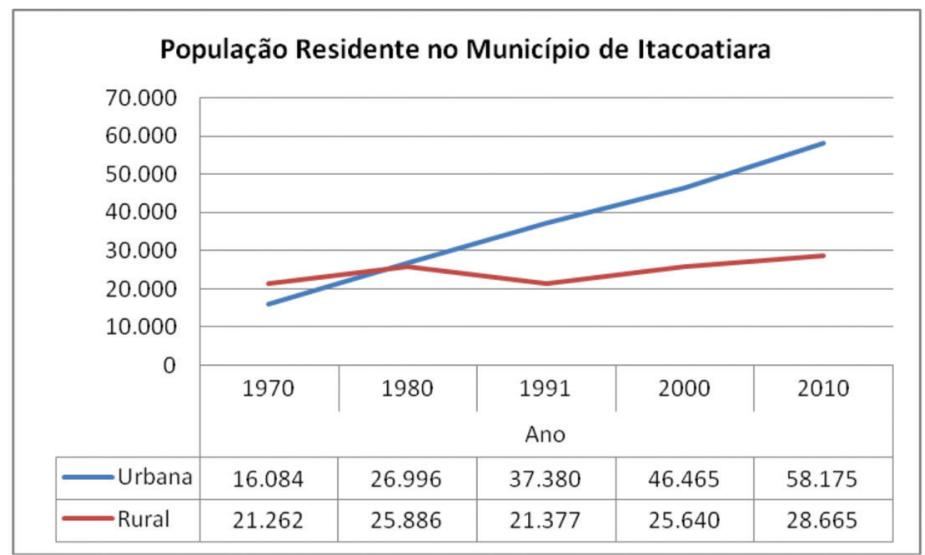

Gráfico o1. População residente no município de Itacoatiara de 1970-2010. Fonte: INSTITUTO BRASILEIRO DE GEOGRAFIA E ESTATÍSTICA.

Censo Demográfico 1970-2010.

Gráfico o2. População residente no município de Parintins de 1970-2010.

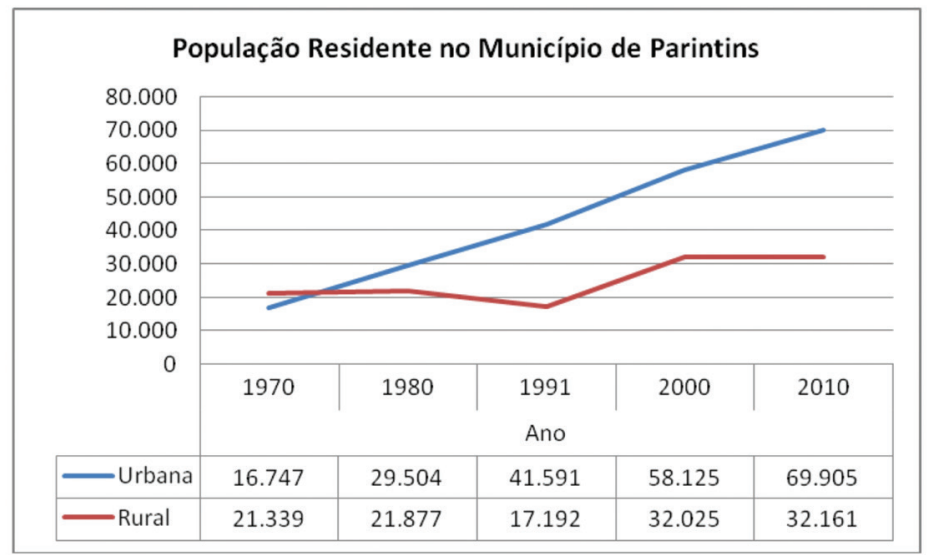

Fonte: INSTITUTO BRASILEIRO DE GEOGRAFIA E ESTATÍSTICA. Censo Demográfico 1970-2010. 